\title{
Initial estimate of the contribution of cryospheric change in China to sea level rise
}

\author{
REN JiaWen*, YE BaiSheng, DING YongJian \& LIU ShiYin \\ State Key Laboratory of Cryospheric Sciences, Cold and Arid Regions Environmental and Engineering Research Institute, Chinese Academy of \\ Sciences, Lanzhou 730000, China
}

Received November 13, 2010; accepted March 14, 2011

\begin{abstract}
Recent studies have shown that cryospheric melting is becoming the dominant factor responsible for sea level rise, and that the melt-water from mountain glaciers and ice caps has comprised the majority of the cryospheric contribution since 2003. Analysis of the estimations of cryospheric melt-water and precipitation in glacier regions indicated that the potential contribution of the cryosphere in China is 0.14 to $0.16 \mathrm{~mm} \mathrm{a}^{-1}$, of which approximately $0.12 \mathrm{~mm} \mathrm{a}^{-1}$ is from glaciers. The contribution of glaciers in the outflow river basins is about $0.07 \mathrm{~mm} \mathrm{a}^{-1}$, accounting for $6.4 \%$ of the total from global glaciers and ice caps.
\end{abstract}

cryosphere, sea level rise, glacier, permafrost, snow cover, China

Citation: $\quad$ Ren J W, Ye B S, Ding Y J, et al. Initial estimate of the contribution of cryospheric change in China to sea level rise. Chinese Sci Bull, 2011, 56: 1661-1664, doi: 10.1007/s11434-011-4474-3

The cryosphere is one of most important factors influencing sea level change. China is the country with a mostly developed cryospere in the mid-low latitudes, but no studies have been conducted to evaluate the contribution of the cryosphere in China to sea level change. This is primarily because the cryosphere in China is a small part of the global cryosphere, and the total volume of ice stored in the cryosphere is not known well, especially the total mass balance of glaciers and permafrost melt-water has not been determined.

Due to continuous climate warming, intensive shrinkage of cryosphere has been causing increase in sea level rise. So the estimation of cryospheric melt-water and its contribution to sea level change is receiving a great deal of attention. Indeed, recent studies have shown that cryosphere melting has exceeded the ocean thermal expansion and accounts for the majority of the observed increase in sea level. Furthermore, melt-water from mountain glaciers and ice caps comprises the majority of the cryospheric contribution to sea level rise [1-3]. In addition, several recent attempts have

*Corresponding author (email: jwren@1zb.ac.cn) been made to estimate the total mass balance of glaciers and permafrost melt-water in China. Here, the contribution of cryospheric change in China to sea level rise is discussed based on the results of these recent studies.

The main components of the cryosphere in China are glaciers, permafrost and snow cover, and sea ice, while river ice and lake ice are less common. Based on the glacier inventories completed in the beginning of the 21 st century [4], there are 46377 glaciers with a total area of $59.425 \times 10^{3} \mathrm{~km}^{2}$ and a volume of about $5.600 \times 10^{3} \mathrm{~km}^{3}$ in China. Because this inventory was conducted over 23 years beginning in 1978 and is based on aerial photographs and maps made in the period of the first aerial survey (1950s-1980s), the results do not reflect the present status. Accordingly, a new inventory was started in 2007. The partial results of this study show that the glacier area is $1.2 \%$ larger than previously estimated. According to this ratio, glaciers in China have a total area of $60.138 \times 10^{3} \mathrm{~km}^{2}$ and a total ice volume of $5.667 \times 10^{3} \mathrm{~km}^{3}$ assuming that the thickness of the ice is the same as in the previous inventory. Taking the ice density as $917 \mathrm{~kg} \mathrm{~m}^{-3}$, the water stored in the glaciers is about $5.2 \times 10^{3} \mathrm{~km}^{3}$. 
Approximately half of China, mainly in the north, is covered with frozen ground seasonally. Permafrost is found in the Tibetan Plateau, high mountains surrounding it and the northeast portion of China. The total area of permafrost is about $1489 \times 10^{3} \mathrm{~km}^{2}$, of which about $1299 \times 10^{3} \mathrm{~km}^{2}$ is in the Tibetan Plateau, $116 \times 10^{3} \mathrm{~km}^{2}$ is in the northeast and about $74 \times 10^{3} \mathrm{~km}^{2}$ is in the Tianshan, Altay and other high mountains [5]. The thickness of the permafrost has only been measured at a few sites along the Qinghai-Tibetan railway and highway; therefore, there are few estimates of the total ice volume of the permafrost in China. The latest estimate by Zhao et al. [6] for the Tibetan Plateau was $9.5 \times 10^{3} \mathrm{~km}^{3}$. The thickness of permafrost in the northeast and other high mountains is generally lower than in the Tibetan Plateau. Moreover, the permafrost is discontinuous; therefore, the average thickness is estimated to be slightly less than a half of that of the Tibetan Plateau. However, precipitation is higher in the northeast and high mountains, which results in higher soil moisture. As a result, the proportion of ice in the northeast should be higher than in the Tibetan Plateau. If the proportion of ice within a unit area is taken to be half of that in the Tibetan Plateau, the ice volume in the northeast and other high mountain permafrost is about $0.65 \times 10^{3} \mathrm{~km}^{3}$. Consequently, the total ice volume in the permafrost in China is about $10.15 \times 10^{3} \mathrm{~km}^{3}$, which is equivalent to $9.3 \times 10^{3} \mathrm{~km}^{3}$ of water. When compared with the estimated ice volume for the Northern Hemispheric permafrost of about $11 \times 10^{3}-37 \times 10^{3} \mathrm{~km}^{3}$ [7], this figure seems to be too large. Because there are no other estimates of the amount of permafrost in the Northern Hemisphere permafrost and the only old one may be much less.

Snow cover occurs widely in China. If taking the steady snow cover longer than 60 days, there are three large regions of steady snow cover in China, the Tibetan Plateau, northern Xinjiang and Inner Mongolia-northeastern China. Previous studies gave the total area of steady snow cover regions of about $420 \times 10^{6} \mathrm{~km}^{2}$ [8], but recent studies have shown that it is about $3.4 \times 10^{6} \mathrm{~km}^{2}$ [9]. Based on these values, the average cover depth is $0.041 \mathrm{~m}$ [8], the average density is $160 \mathrm{~kg} \mathrm{~m}^{-3}$ [10], and the annual mean water equivalent of steady snow cover is about $22.3 \mathrm{~km}^{3}$.

Overall, the total water equivalent stored in glaciers, permafrost and snow cover in China is $14.5223 \times 10^{3} \mathrm{~km}^{3}$, of which glaciers account for about $35.8 \%$, permafrost accounts for about $64 \%$ and snow covers only about $0.2 \%$. The estimation error of the glacier water equivalent is relatively low, although the ice thickness has only been measured for a few glaciers, and most values of glacier thickness were determined from empirical formulas. Accordingly, the uncertainty associated with the water equivalent estimations of permafrost and snow cover is much larger than for glaciers.

Numerical studies indicate that the cryosphere in China has generally been decreasing over the past few decades, and this trend seems to have been accelerating since the 1990s [4,11-13]. Variations in glaciers over the past few decades can be evaluated based on comparisons of recent satellite imagines with aerial photographs taken in the 1960s of more than 1700 glaciers and field investigations of dozens of glaciers. The results of such comparisons show that $80 \%$ of glaciers in China are in retreat and that the investigated glaciers, which have a total area of about $20 \times 10^{3} \mathrm{~km}^{2}$, have decreased by an average of $7 \%$ and by as much as $20 \%$ for some glaciers, during the past four decades. There are only a few estimates of the total runoff from glacial melt in China. In early 1990, Yang [14] estimated the total annual runoff from glaciers in China to be $56.4 \mathrm{~km}^{3}$ based on observation data collected in several glacier basins and runoff modulus. Later, Kang et al. [15] obtained a revised value of $60.5 \mathrm{~km}^{3}$. Xie et al. [16] estimated the total runoff to be 61.6 $\mathrm{km}^{3}$ by use of a glacial system model. These estimated values were likely lower because the glacier melting data used in these studies were mainly obtained in the 1980s and 1990s and glacial melt has been much more intense since the late 1990s. More recently, Gao et al. [17,18] developed a basin scale Degree-Day model based on a glacier digital elevation model and data from meteorological stations for the time series recovery of glacier mass balance and melting runoff in the Tarim and Yarkant basins. In addition, an attempt to estimate the annual runoff of total glaciers in China was made using this method [19]. The results indicate that the annual average runoff was $62.3 \mathrm{~km}^{3}$ during 1961-2006 and $79.4 \mathrm{~km}^{3}$ during $2001-2006$, of which $46.7 \mathrm{~km}^{3}$ is from glaciers in the outflow river basins, occupying about $59 \%$ of total glacial runoff. Since all of these values before 2000 are greater than $60 \mathrm{~km}^{3}$ consistently, it is reasonable to assume that total runoff has increased to $800 \mathrm{~km}^{3}$ at present because glacier melting has been intensifying in response to climate warming in recent years.

After identifying the total melt-water, it is necessary to determine how much of the mass income is from precipitation on glaciers because the accumulation has an effect on sea level lowering. In other words, only the net mass balance, i.e. the difference between melting and precipitation, is an eventual contributor of glaciers to sea level change. Because direct observation of glacier mass balance is very laborious it has only been conducted for about 12 glaciers; therefore, it is impossible to extend these values to thousands of glaciers. Nevertheless, the mass gain can be estimated from the precipitation distribution. According to the investigation data obtained in past decades, the annual precipitation is about $600 \mathrm{~mm}$ in the east Tianshan Mountains and north slope of the Himalayas, 400-500 $\mathrm{mm}$ in the Qilian and Tanggula Mountains, less than $300 \mathrm{~mm}$ in the West Kunlun Mountains and north Tibetan Plateau, around 1000 $\mathrm{mm}$ in the Karakorum and Pamir, $700-1400 \mathrm{~mm}$ in the Hengduan Mountains and more than $1000 \mathrm{~mm}$ in southeast Tibet. From these a rough estimate for annual precipitation is about $600 \mathrm{~mm}$ on average for all glaciers in China. Accordingly, we can obtain a roughly estimated value of total 
mass gain for all glaciers in China of about $36 \mathrm{~km}^{3}$. As a result, the total net mass balance of glaciers in China is about $44 \mathrm{~km}^{3}$ if the average annual precipitation is subtracted from the total melt-water. Conversely, the water balance mode for a basin can also be used to assess the mass balance of glaciers in the basin. For example, Gao [19] recently attempted to estimate glacier mass balance in various basins and obtained an average net mass loss per unit area of $327 \mathrm{~mm}$ for all glaciers between 1991 and 2006 and larger than $600 \mathrm{~mm}$ between 2001 and 2006. If the net mass loss since 2006 is assumed to be $700 \mathrm{~mm}$ or more, the total net mass balance of glaciers in China is greater than $42 \mathrm{~km}^{3}$ $\mathrm{a}^{-1}$ since 2006, which is consistent with the results from the precipitation based estimate.

It is extremely difficult to observe permafrost melt-water directly; therefore, there are no estimates of permafrost melt-water except for one based on observation of the proportion of ice within a depth of $10 \mathrm{~m}$ at some sites along the Qinghai-Tibet Highroad. Assuming a 0.2-0.4 m increment of the active layer depth from early this century to 2050, this estimate gives a value of $5-11 \mathrm{~km}^{3}$ for the annual permafrost melt-water in the Tibetan Plateau [20]. Permafrost shrinkage is occurring more rapidly in the Tianshan Mountains and northeast China. For example, the permafrost thickness decreased by $7.7 \mathrm{~m}$ from 1992 to 2008 in the Urumqi River basin, Tianshan [21], and the southern limit of permafrost in northeast China has shifted northwards $40-120 \mathrm{~km}$ over the past 50 years [22]. Around the Heihe-Beian Highroad in Xiao Hinggan Mountains, the patchy permafrost area has decreased to $2 \%$ from $20 \%$ in the 1970s [23,24]. Moreover, the temperature at $6 \mathrm{~m}$ in the permafrost along the Qinghai-Tibet Highroad increased by $0.43^{\circ} \mathrm{C}$ from 1996-2006 [25], while the permafrost temperature in the Urumqi River basin increased by $1^{\circ} \mathrm{C}$ at $5 \mathrm{~m}$ and $0.6^{\circ} \mathrm{C}$ at $10 \mathrm{~m}$ during the same period [26]. These findings imply that the increase in permafrost temperature in the Tianshan Mountains double that of the Tibetan Plateau. It is lack of the temperature observation for permafrost in northeast China, but the temperature change is expected to become larger than that for the Tibetan Plateau at present according to larger change in permafrost area in northeast China. Assuming that the melt-water is double that of the Tibetan Plateau per unit area, the annual melt-water in northeast China and other areas such as the Tianshan Mountains is about $1.3-2.8 \mathrm{~km}^{3}$. Consequently, the total annual melt-water from permafrost in China is approximately $6-14 \mathrm{~km}^{3}$.

Of the main cryospheric components mentioned above, glaciers have a relatively direct effect on changes in sea level because melt-water from glaciers drains directly into rivers. Taking the ocean area as $3.62 \times 10^{8} \mathrm{~km}^{2}$ and the sea water density as $1028 \mathrm{~kg} \mathrm{~m}^{-3}$ [27], the potential contribution of glaciers in China to sea lever rise is currently about $0.12 \mathrm{~mm} \mathrm{a}^{-1}$. It should be noted that all glaciers in China are in the inland mountains and some of these drain melt water into inland rivers; therefore, melt water from these glaciers does not flow into the ocean directly and only has the potential contribution to sea level rise through the water cycle. Accordingly, glaciers in outflow river basins in China have a contribution of about $0.07 \mathrm{~mm} \mathrm{a}^{-1}$ to sea level rise.

On a global scale, mountain glaciers and high latitude ice caps have a great effect on sea level change. In the IPCC report [27], their contribution to sea level rise was about 0.5 $\mathrm{mm} \mathrm{a}^{-1}$ from 1961-2003, and about $0.8 \mathrm{~mm} \mathrm{a}^{-1}$ from 1993-2003. Recent results [1,2] show that this value has increased to $1.1 \mathrm{~mm} \mathrm{a}^{-1}$, which is larger than other any contributing factors and accounts for $44 \%$ of the observed sea level rise since 2003 (Table 1). Glaciers in China occupy about $12 \%$ of the area of the global glaciers and ice caps, accounting $4 \%-11 \%$ of the total volume of the global glaciers and ice caps (there is large uncertainty in the estimated volume of global glaciers and ice caps), and their potential contribution to sea level rise is currently about $6 \%-11 \%$ of that of global glaciers and ice caps, accounting for about $2.8 \%-4.8 \%$ of the observed sea level rise (Table 1).

Melt water from permafrost does not all form surface runoff; therefore, it is insufficient to understand the water cycle of permafrost. If it is assumed that permafrost meltwater also contributes to increases in sea level, the maximum contribution of total annual melt-water from permafrost in China is $0.016-0.038 \mathrm{~mm} \mathrm{a}^{-1}$. Because this is only a seasonal store of precipitation on the land, snow cover is generally regarded unimportant to changes in sea level [27].

Overall, the maximum potential contribution of the cryosphere in China to sea level rise is about $0.14-0.16 \mathrm{~mm}$ $\mathrm{a}^{-1}$ at present, if glacier melting in the inland river basins and permafrost melt-water are considered.

The results of recent studies of sea level change and its causes show that since 2003 a major portion of sea level rise can be attributed to cryosphere melting, and that glaciers and ice caps make the largest contribution of cryospheric components, although the contribution from Greenland and Antarctic ice sheets is increasing rapidly.

If permafrost melt-water and the glacier runoff in the inland river basins are counted, the overall contribution of the cryosphere in China to sea level rise is $0.14-0.16 \mathrm{~mm}$ $\mathrm{a}^{-1}$, accounting for $5.6 \%-6.4 \%$ of the observed sea level rise, $12.7 \%-14.5 \%$ of the contribution from global glaciers and ice caps and $6.8 \%-7.8 \%$ of that from the global cryosphere. The glaciers in outflow river basins have a contribution of $0.07 \mathrm{~mm} \mathrm{a}^{-1}$ to sea level rise, accounting for $6.4 \%$ of that from global glaciers and ice caps.

On a global scale, the ice volume of the cryosphere in China is not large and therefore has a relatively minor impact on changes in sea level. However, because of the intensive shrinkage of the cryosphere, it is valuable to understand the contribution of the cryosphere in China to sea level rise. Here, we make a first attempt to provide a rough estimate of this contribution. To enable a better understanding of 
Table 1 Potential contributions of the cryosphere in China and the world to sea level rise ${ }^{\text {a) }}$

\begin{tabular}{|c|c|c|c|c|c|}
\hline $\begin{array}{l}\text { Cryosphere } \\
\text { components }\end{array}$ & $\begin{array}{l}\text { Ice volume } \\
\left(103 \mathrm{~km}^{3}\right)\end{array}$ & $\begin{array}{l}\text { Potential sea level } \\
\text { rise if melted }(\mathrm{m})\end{array}$ & $\begin{array}{l}\text { Annual net loss } \\
\text { water eq. }\left(\mathrm{km}^{3}\right)\end{array}$ & $\begin{array}{l}\text { Contribution to sea } \\
\text { level rise }\left(\mathrm{mm} \mathrm{a}^{-1}\right)\end{array}$ & $\begin{array}{c}\text { Percentage } \\
(\%)\end{array}$ \\
\hline \multicolumn{6}{|l|}{ Global } \\
\hline Glaciers \& ice caps & $50-130$ & $0.15-0.37$ & 410 & 1.1 & 44 \\
\hline Greenland \& Antarctic ice sheets & 27600 & 63.9 & 354 & 0.95 & 38 \\
\hline Permafrost (NH) & $11-37$ & $0.03-0.10$ & - & - & - \\
\hline Snow cover $(\mathrm{NH})$ & $0.5-5$ & $0.0113-0.0134$ & - & - & - \\
\hline \multicolumn{6}{|l|}{ China } \\
\hline Glaciers & 5.667 & 0.014 & 44 & 0.12 & 4.8 \\
\hline Permafrost & 10.15 & 0.025 & $6-14$ & $0.016-0.038$ & $0.7-1.5$ \\
\hline Snow cover & 0.022 & 0.00006 & - & - & - \\
\hline
\end{tabular}

a) The ice volume and potential sea level rise for global cryosphere from [27], contribution of global cryosphere to sea level rise from [1], annual net loss water inversely calculated from these values.

this contribution, it is necessary to undertake a more systematic approach to the basin scale mass balance of glaciers and permafrost melting process and to develop specific models such as a basin scale mass balance model, dynamic model of glaciers and water cycle model of various permafrost regions.

Although the cryospheric impact on changes in sea level is attracting increasing attention, there is large uncertainty in the estimation of cryospheric melting on the global scale, as well as regionally. Moreover, observations and modeling of changes in sea level need to be further developed. For example, the 2007 IPCC Report [28] states that the sea level rise is about $3.1 \mathrm{~mm} \mathrm{a}^{-1}$ and thermal expansion of sea water is the primary contributor to this increase. However, the forward looking results from then on [1,2] show that both sea level rise and sea water thermal expansion is decreasing to some extent and cryospheric melting has become the primary contributor. In June 2010, the IPCC held a workshop on sea level rise and ice sheet instabilities in Malaysia and more results of monitoring and modeling of sea level rises and cryospheric melting were presented. Some results suggest that the rate of sea level rise is higher than $3.1 \mathrm{~mm}$ $\mathrm{a}^{-1}$ at present, while contributions from glaciers and ice sheets are close to those shown in Table 1 [3]; however, these results were only distributed by IPCC in abstract volume and the related papers have not been published to date.

This work was supported by the National Basic Research Program of China (2007CB411501).

1 Cazenave A, Dominh K, Guinehut S, et al. Glob Planet Change, 2009, 65: 83-88

2 Cazenave A, Lombard A, Llovel W. Comptes Rendus Geosci, 2008, 340: 761-770

3 IPCC. Workshop Report of the Intergovernmental Panel on Climate Change Workshop on Sea Level Rise and Ice Sheet Instabilities. IPCC Working Group I Technical Support Unit, University of Bern, Bern, Switzerland, 2010

4 Shi Y F. Concise Glacier Inventory of China (in Chinese). Shanghai: Popular Science Press, 2005

5 Ding Y J, Ren J W. National Assessment Report on Climate Change of China, Vol.1. Beijing: Science Press, 2010
6 Zhao L, Ding Y J, Liu G Y, et al. J Glaciol Geocryol, 2010, 32: 1-9

7 Zhang T J. Polar Geogr, 1999, 23: 132-154

8 Li P J. Acta Geogr Sin, 1993, 48: 505-515

9 Li X, Cheng G D, Jin H J, et al. Glob Planet Change, 2008, 62: 210-218

10 Che T, Li X, Jin R, et al. Ann Glaciol, 2008, 49: 145-154

11 Wang S M, Liu S Y. In: Qin D H, ed. Climate and Environment Changes in China (in Chinese). Vol. I: Climate and Environment Changes in China and Their Projections. Beijing: Science Press, 2005. 104-186

12 Ding Y J, Liu S Y, Li J, et al. Ann Glaciol, 2006, 43: 97-105

13 Xiao C D, Liu S Y, Zhao L, et al. Ann Glaciol, 2007, 46: 382-390

14 Yang Z N. The Glacier Water Resources in China (in Chinese). Lanzhou: Gansu Science and Technology Press, 1991. 137-148

15 Kang E S, Yang Z N, Lai Z M, et al. In: Shi Y F, ed. Glaciers and Their Environments in China (in Chinese). Beijing: Science Press, 2000. 190-233

16 Xie Z C, Wang X, Kang E S, et al. J Glaciol Geocryol, 2006, 28 : 457-466

17 Gao X, Ye B S, Zhang S Q, et al. Sci China Earth Sci, 2010, 40: 654 665

18 Gao X, Zhang S Q, Ye B S, et al. J Glaciol Geocryol, 2010, 32: 445453

19 Gao X. Dissertation for the Master Degree of Science, the Graduate University of Chinese Academy of Sciences. Lanzhou: Cold and Arid Regions Environmental and Engineering Research Institute, Chinese Academy of Sciences, 2010

20 Ding Y J, Pan J H. In: Qin D H, ed. Climate and Environmental Changes in China. Vol. II: Impacts, Adaptation and Mitigation of Climate and Environmental Changes (in Chinese). Beijing: Science Press, 2005. 114-194

21 Zhao L, Liu G Y, Jiao K Q, et al. J Glaciol Geocryol, 2010, 32: 223 230

22 Chang X L, Jin H J, He R X, et al. J Glaciol Geocryol, 2008, 30: 176-182

23 Yu Q H, Bai Y, Jin H J, et al. J Glaciol Geocryol, 2008, 30: 461-468

24 Jin H J, Yu S P, Lu L Z, et al. J Glaciol Geocryol, 2006, 28: 467-476

25 Wu Q B, Zhang T J. J Geophys Res, 2008, 113: D13108, doi: 10.1029/ 2007JD009539

26 Liu G Y. Dissertation for the Master Degree of Science, the Graduate University of Chinese Academy of Sciences. Lanzhou: Cold and Arid Regions Environmental and Engineering Research Institute, Chinese Academy of Sciences, 2008

27 Lemke P, Ren J. Contribution of Working Group I to the Fourth Assessment Report of the Intergovernmental Panel on Climate Change. Cambridge: Cambridge University Press, 2007. 337-383

28 IPCC. Contribution of Working Group I to the Fourth Assessment Report of the Intergovernmental Panel on Climate Change. Cambridge: Cambridge University Press, 2007. 5-7

Open Access This article is distributed under the terms of the Creative Commons Attribution License which permits any use, distribution, and reproduction in any medium, provided the original author(s) and source are credited. 